\title{
ANALISIS PENERAPAN TARGET COSTING SEBAGAI SISTEM PENGENDALIAN BIAYA PRODUKSI (Studi Kasus Pada UD. Winda Kabupaten Gowa Provinsi Sulawesi Selatan)
}

\author{
Idrawahyuni $^{1)}$, Muhammad Adil ${ }^{2)}$, Muhammad Nasrun ${ }^{3)}$,Dedi Akbar Herianto ${ }^{4)}$ \\ ${ }^{1,2,3,4)}$ Fakultas Ekonomi dan Bisnis, Universitas Muhammadiyah Makassar \\ Email: idrawahyuni.idris@gmail.com
}

\begin{abstract}
Abstrak
Penelitian ini bertujuan untuk mengetahui klasifikasi biaya produksi mebel pada UD Winda, untuk menganalisa pendekatan target costing agar dapat meningkatkan efisiensi biaya produksi mebel dan untuk membandingkan antara biaya standar dan target costing. Dari hasil analisis mengenai perhitungan standar biaya produksi dalam memproduksi mebel, terlihat bahwa standar biaya produksi untuk lemari 2 Pintu sebesar Rp. 971.620, untuk lemari 3 Pintu sebesar Rp. 1.209.119. Berdasarkan hasil analisis perbandingan penerapan target costing dengan standar biaya produksi perusahaan mengenai pelaksanaan target costing jauh lebih efisien.
\end{abstract}

Kata kunci: Target Costing, Sistem Pengendalian, Biaya Produksi

Abstract

This study aims to determine the classification of furniture production costs at UD Winda, to analyze the target costing approach in order to improve the efficiency of furniture production costs and to compare between standard costs and target costing. From the analysis of the calculation of the standard production costs in producing furniture, it can be seen that the standard production cost for a 2-door cabinet is Rp. 971,620, for a 3-door cupboard of Rp. 1,209,119. Based on the results of a comparative analysis of the implementation of target costing with the company's standard production costs regarding the implementation of target costing is much more efficient.

Keywords: Target Costing, Control System, Production Cost

\section{PENDAHULUAN}

Persaingan yang terjadi di semua lini usaha pada era perdagangan bebas membawa berbagai macam dampak bagi perekonomian Indonesia. Adapun dampak positifnya adalah memberikan peluang bagi Indonesia untuk mengekspor produk yang semakin luas. Sedangkan dampak negatifnya adalah persaingan yang terjadi bukan hanya antar pelaku bisnis domestik, tetapi melibatkan pula pelaku bisnis dari luar negeri yang semakin bebas memasarkan produk di Indonesia.

Sejalan dengan perkembangan teknologi dewasa ini, jenis-jenis produk makin bertambah jumlahnya. Seiring dengan itu pula, persoalan yang dihadapi perusahaan terutama perusahaan manufaktur akan semakin kompleks. Hal ini menuntut manajemen perusahaan untuk menentukan suatu tindakan dengan memilih berbagai alternatif dan kebijakan dalam mengambil keputusan yang sebaikbaiknya agar tujuan perusahaan dapat tercapai. Tujuan yang utama adalah optimalisasi laba atau keuntungan. Perusahaan yang ingin berkembang dan bertahan hidup harus mampu menghasilkan produksi yang tinggi dengan kualitas yang baik.

Menurut (Hansen dan Mowen, 2001) bahwa biaya produksi merupakan biaya yang digunakan dalam mengubah bahan baku menjadi barang jadi. Pada perusahaan manufaktur, biaya produksi dapat dibedakan menjadi biaya utama dan biaya konversi. Biaya utama terdiri dari bahan langsung dan upah langsung, sedangkan biaya konversi terdiri dari upah tidak langsug dan biaya tidak langsung. Biaya produksi ini juga biasanya terdiri 
dari tiga unsur yaitu bahan baku langsung, tenaga kerja langsung dan overhead pabrik. dimana bahan baku langsung adalah semua bahan baku yang membentuk bagian integral dan produk jadi dan dimasukkan secara ekspilit dalam perhitungan biaya produk. Tenaga kerja langsung adalah tenaga kerja yang melakukan konversi bahan baku langsung menjadi produk jadi dan dapat dibebankan secara layak ke produk tertentu, sedangkan overhead pabrik merupakan semua biaya manufaktur yang tidak ditelusuri secara langsung ke output tertentu. Biaya produksi ini juga merupakan unsur penting dalam perhitungan harga pokok produksi.

Oleh karena itu bagi perusahaan manufaktur, biaya produksi merupakan faktor penting dalam berhasil atau tidaknya perusahaan ditinjau dari segi finansial. Biaya produksi ini merupakan pos biaya yang besar dibanding dengan pos biaya lainnya. Jadi tujuan utama dalam pengendalian biaya produksi adalah untuk dapat mempergunakan sumber-sumber ekonomi untuk berproduksi secara efektif, sehingga tidak terjadi pemborosan biaya dalam berproduksi.

Umumnya perusahaan beroperasi dengan mengembangkan dan memproduksi barang/jasa terlebih dahulu. Kemudian mulai menghitung biaya yang dikeluarkan untuk jenis produksi tersebut dan menetapkan harga jual bagi produknya, setelah itu produk siap dipasarkan. Namun dalam metode target costing, proses yang terjadi justru sebaliknya. Target costing mempertimbangkan seluruh biaya produk atau jasa dalam siklus hidup produk dan bertujuan untuk menurunkan biaya total sebuah produk atau jasa. Tujuan yang ingin dicapai oleh perusahaan dengan menerapkan target costing adalah untuk menurunkan total biaya dari total biaya sebelumnya sehingga perusahaan pun bisa mendapatkan laba yang maksimal tanpa harus menaikan harga jualnya.

Konsep target costing sangat sesuai sejalan dengan meningkatnya persaingan serta tingkat penawaran yang jauh melampaui tingkat permintaan, maka kekuatan pasar memberi pengaruh yang semakin besar terhadap tingkat harga. Untuk itulah diperlukan target costing untuk dapat mencapai tujuan perusahaan dalam rangka pengurangan biaya (cost reduction), yang pada akhirnya akan membawa dampak terhadap tingkat harga yang kompetitif.

Sebagai salah satu manajemen inovasi, penerapan target costing dalam suatu perusahaan juga harus memperhatikan halhal yang berkaitan dengan keberhasilan implementasi dari adanya inovasi tersebut. Pada saat target costing mulai diambil dan diimplementasikan oleh operasi bisnis organisasi di dalam lingkungan bisnis yang lain maka dapat diasumsikan bahwa suatu hal yang baru tentang pendekatan tersebut dapat dipelajari dengan memperhatikan apa yang sedang terjadi dengan konteks bisnis lainnya.

Filosofi target costing mengharuskan manajemen biaya yang agresif terjadi pada tahap perencanaan, tahap desain produk, dan tahap produksi. Target costing didorong oleh analisis pasar dan analisis pesaing. Dengan merancang biaya yang rendah, perusahaan akan mendapatkan penghematan biaya.

Terkait target costing dengan pengendalian biaya produksi merupakan salah satu bagian dari langkah-langkah intern yang dilakukan perusahaan dalam usaha meningkatkan efisiensi. Pengendalian biaya terutama harus diselaraskan terhadap tujuan yang ingin dicapai oleh perusahaan, salah satu tujuan yang ingin dicapai oleh perusahaan adalah memaksimalkan target costing, oleh karena itu dengan mengendalikan biaya produksi perusahaan berharap dapat mencapai target costing yang telah di rencanakan sebelum perusahaan melakukan proses produksi.

Beberapa peneliti pernah melakukan penelitian tentang penerapan target costing, diantaranya (Malue, 2013) dengan judul Analisis Penerapan Target Costing 
Sebagai Sistem Pengendalian Biaya Produksi Pada PT. Celebes Mina Pratama. Tujuannya untuk membandingkan sistem pengendalian biaya selama ini digunakan oleh perusahaan dengan metode target costing. Metode yang digunakan yaitu analisis kuantitatif komparatif. Hasil penelitiannya yaitu penerapan target costing pada PT. Mina Pratama lebih efisien jika dibandingkan dengan yang dilakukan perusahaan selama ini. Lain halnya pada penelitian yang dilakukan oleh (Caroline, T. C. dan Wokas, 2016) dengan judul Analisis Penerapan Target Costing dan Activity Based Costing Sebagai Alat Bantu Manajemen Dalam Pengendalian Biaya ProduksiI Pada UD. Bogor Bakery. Tujuannya untuk membandingkan keefektifan penerapan metode Target Costing dan Activity-Based Costing. Metode yang digunakan yaitu kuantitatif komparatif. Hasil penelitiannya yaitu Activity-Based Costing lebih tepat diterapkan dari pada UD. Bogor Bakery dibanding menggunakan Target Costing.

Tujuan yang ingin dicapai oleh perusahaan dengan menerapkan target costing adalah untuk menentukan harga pokok produk sesuai dengan yang diinginkan (target) sebagai dasar penetapan harga jual produk untuk memperoleh laba yang diinginkan oleh perusahaan. Hal ini sangat baik untuk diterapkan oleh perusahaan agar perusahaan dapat mengelola biaya dengan baik, dan untuk mencapai tujuan perusahaan, perusahaan membentuk sebuah tim untuk pengembangan produk yang bertanggungjawab dan merancang produk yang dapat dibuat dengan biaya yang tidak lebih besar dari target biaya yang telah dihitung oleh perusahaan, sehingga dengan menggunakan pendekatan target costing, maka diharapkan dapat dijadikan sebagai alat pengendalian biaya produksi mebel pada UD Winda. Berdasarkan uraian diatas, maka yang menjadi fokus penelitian adalah apakah penerapan target costing dapat digunakan sebagai sistem pengendalian biaya prduksi di UD Winda.

\section{TINJAUAN PUSTAKA}

Akuntansi biaya mengatur sumber-sumber ekonomi yang digunakan untuk menghasilkan produk atau jasa dengan satuan uang. Satuan pengukur yang digunakan untuk menyatakan nilai uang dari berbagai sumber ekonomi yang digunakan tersebut dikenal dengan istilah "cost". Pemakaian istilah cost selalu dikaitkan dengan objek atau tujuan dari sumber-sumber penggunaan ekonomi.

Biaya memiliki berbagai macam arti tergantung maksud dari pemakai istilah tersebut. Mulyadi membedakan pengertian biaya ke dalam arti luas dan arti sempit antara lain sebagai berikut (Mulyadi, 2012), dalam arti luas biaya adalah pengorbanan sumber ekonomis yang diukur dalam satuan uang, yang telah terjadi atau mungkin terjadi untuk mencapai tujuan tertentu. Dalam arti sempit biaya merupakan bagian dari harga pokok yang dikorbankan dalam usaha untuk memperoleh penghasilan.

Supriyono, (2010) juga membedakan biaya ke dalam dua pengertian yang berbeda yaitu biaya dalam arti cost dan biaya dalam arti expense Biaya dalam arti cost (harga pokok) adalah "Jumlah yang dapat diukur dalam satuan uang dalam rangka pemilikan barang dan jasa yang diperlukan perusahaan, baik pada masa lalu (harga perolehan yang telah terjadi) maupun pada masa yang akan datang (harga perolehan yang akan terjadi). Sedangkan expense (beban) adalah "Biaya yang dikorbankan atau dikonsumsi dalam rangka memperoleh pendapatan (revenues) dalam suatu periode akuntansi tertentu."

Klafisikasi Biaya berdasarkan fungsinya yaitu:

1. Biaya Produksi merupakan biaya-biaya yang terjadi untuk mengolah bahan baku menjadi produk jadi yang siap untuk dijual. Menurut objek pengeluarannya, biaya produksi dapat dibagi menjadi: biaya bahan baku, biaya tenaga kerja, dan biaya overhead pabrik. 
2. Biaya Pemasaran merupakan biayabiaya yang terjadi untuk melaksanakan kegiatan pemasaran produk.

3. Biaya Administrasi dan Umum merupakan biaya-biaya yang terjadi untuk mengkoordinasi kegiatan produksi dan pemasaran produk.

\section{Sistem Informasi Biaya}

Perusahaan dapat dipandang sebagai suatu sistem yang memproses masukan untuk menghasilkan keluaran. Perusahaan yang bertujuan mencari laba maupun yang tidak bertujuan mencari laba mengolah masukan berupa sumber ekonomi untuk menghasilkan keluaran berupa sumber ekonomi lain yang nilainya harus lebih tinggi daripada nilai masukannya. Oleh karena itu baik dalam usahan bermotif laba maupun yang tidak bermotif laba, manajemen selalu berusaha agar nilai keluaran lebih tinggi dari nilai keluaran yang dikorbankan untuk menghasilkan keluaran tersebut, sehingga kegiatan organisasi dapat menghasilkan laba (untuk perusahaan bermotif laba) atau sisa hasil usaha (untuk perusahaan yang tidak bermotif laba). Dengan laba atau sisa hasil usaha tersebut, perusahaan akan memiliki kemampuan untuk berkembang dan tetap mampu mempertahankan eksistensinya sebagai suatu sistem di masa yang akan datang.

Dengan demikian untuk menjamin bahwa suatu kegiatan usaha menghasilkan nilai keluaran yang lebih tinggi daripada nilai masukan diperlukan alat untuk mengukur nilai masukan yang dikorbankan untuk menghasilkan keluaran. Akuntansi biaya berfungsi mengukur pengorbanan nilai masukan tersebut guna menghasilkan informasi bagi manajemen yang salah satu manfaatnya adalah untuk mengukur apakah kegiatan usahanya menghasilkan laba atau sisa hasil usaha tersebut. Akuntansi biaya juga menghasilkan informasi biaya yang dapat dipakai oleh manajemen sebagai dasar untuk merencanakan alokasi sumber ekonomi yang dikorbankan untuk menghasilkan keluaran.
Sistem informasi biaya merupakan sistem yang membantu manajemen dalam mentapkan sasaran laba perusahaan, target laba departemen, mengevaluasi efektifitas rencana perusahaan, mengungkapkan kegagalan dan keberhasilan dalam bentuk tanggung jawab yang spesifik dan menganilisis serta memutuskan penyesuaian dan perbaikan yang diperlukan agar tujuan atau sasaran organisasi dapat dicapai.

Informasi biaya yang baik, tepat dan akurat diperlukan oleh setiap pemakai informasi biaya, hal tersebut dapat dipenuhi jika:

1. Informasi biaya yang digunakan secara sistematis dan komperatif, sehingga informasi biaya yang digunakan dapat diandalkan dalam memutuskan tindakan apa yang akan memberikan hasil yang optimal bagi perusahaan.

2. Informasi yang digunakan harus terkoordinasi dan terintegraasi sehingga informasi yang tersedia dapat digunakan oleh manajer perusahaan dan mudah dipahami dan dimengerti oleh pemakai.

3. Mencerminkan otoritas, sehingga masing-masing manajer dapat dimintai pertanggungjawabannya.

4. Informasi sebaiknya dapat memfokuskan perhatian manajemen.

Tanpa informasi biaya, manajemen tidak memiliki ukuran apakah masukan yang dikorbankan memiliki nilai ekonomi yang lebih rendah daripada nilai keluarannya, sehingga tidak memiliki informasi apakah kegiatan usahanya menghasilkan laba atau sisa hasil usaha yang sangat diperlukan untuk mengembangkan dan mempertahankan eksistensi perusahaannya. Begitu juga tanpa informasi biaya, manajemen tidak memiliki dasar untuk mengalokasikan berbagai sumber ekonomi yang dikorbankan dalam menghasilakan sumber ekonomi lain

\section{Target Costing}

Rahmaji, (2013) menyatakan bahwa target 
costing atau biaya pokok sasaran adalah sebuah strategi dimana perusahaan pertama-tama menetapkan harga jual dimana mereka dapat menjual sebuah produk atau jasa baru, dan kemudian merancang sebuah produk atau jasa yang dapat diproduksi pada suatu biaya yang cukup rendah guna memberikan margin laba yang memadai.

Metode ini diterapkan untuk mendorong berbagai departemen yang terlibat dalam desain dan produksi produk dalam upaya mencari cara-cara yang lebih mudah untuk mencapai keistimewahan dan mutu produk yang sama atau lebih baik. Target costing digunakan selama tahap perencanaan dan menuntun dalam pemilihan produk serta proses desain yang akan dihasilkan suatu produk yang dapat diproduksi pada biaya yang diijinkan dan pada suatu tingkat laba yang dapat diterima. Target costing juga memberikan perkiraan harga pasar produk, volume penjualan, dan tingkat fungsionalitas.

\section{Prinsip-Prinsip Penerapan Target Costing}

Hansen dan Mowen, (2001) menyatakan prinsip penerapan target costing yaitu:

1. Price Led Costing, dalam prinsip ini sistem target costing menetapkan target biaya dengan mengurangi required profit margin dari harga pasar yang diharapkan. Harga pasar dikendalikan oleh situasi pasar dan target laba ditentukan persyaratan keuangan dari suatu perusahaan dan industrinya

\section{Target Biaya $=$ Harga Pasar - Laba Kotor yang diinginkan}

2. Focus on Customers, dalam prinsip ini sistem target costing digerakkan oleh pasar (market driven). Persyaratan pelanggan atas kualitas, biaya dan waktu secara simultan diintegrasikan ke dalam produk, keputusan proses, dana mengarahkan analisis biaya. Target biaya tidak boleh dicapai dengan mengorbankan features yang diinginkan pelanggan, menurunkan kinerja atau keandalan suatu produk atau dengan menunda pengenalan produk di pasar.

a) Focus on Design, dalam prinsip ini sistem target costing mempertimbangakan desain produk dan proses sebagai kunci terhadap manajemen biaya. Perusahaan menghabiskan lebih banyak waktu pada tahap desain dan mengurangi waktu sampai ke pasar (time to market) dengan menghilangkan perubahan-perubahan yang mahal dan menghabiskan banyak waktu yang diperlukan dikemudian hari. Sebaliknya metode reduksi biaya tradisional memfokuskan pada skala ekonomi, kurva pembelajaran, dan perbaikan hasil dalam mengelola biaya. Empat sub-prinsip yang mencakup implikasi dari orientasi desain ini adalah:Sistem target costing mengelola biaya sebelum biaya terjadi.

b) Sistem target costing menyaring semua keputusan perekayasaan melalui suatu customer value impact assesment sebelum diintegrasikan ke dalam desain.

c) Sistem target costing mendorong semua fungsi perusahaan yang berpartisipasi untuk menguji desain, sehingga perubahan produk dan perekayasaan dilakukan sebelum produk diproduksi.

d) Target costing mendorong simultaneous engineering dari produk dan proses daripada sequental engineerin. Hal ini mengurangi waktu pengembangan dan biaya dengan memungkinkan masalah lebih cepat diatasi dalam proses.

3. Tim Cross-functional, (Rahmat, 2013) mengemukakan bahwa: Target costing menggunakan tim produk dan proses, dengan anggota-anggota dari desain dan perekayasaan manufacturing, produksi, penjualan dan pemasaran, pengadaan material, akuntansi biaya, servis dan pendukung. Tim lintas fungsional ini juga termasuk peserta 
dari luar, seperti pemasok, pelanggan, dealer, distributor, dan penyedia servis.

4. Pengurangan Biaya dalam Siklus Hidup (life Cycle), dalam prinsip ini target costing mempertimbangkan seluruh biaya produk selama hidupnya, seperti harga pembelian, biaya operasi, pemeliharaan dan reparasi, serta biaya distribusi. Tujuan target costing adalah meminimalisir biaya daur hidup (life cycle cost) baik untuk pelanggan maupun produsen.

5. Value Chain Involvement (Keterlibatan Rantai Nilai), dalam prinsip ini target costing melibatkan seluruh anggota rantai, seperti pemasok, dealer, distributor, dan penyedia asa dalam proses. Target costing didasari hubungan jangka panjang yang saling menguntungkan dengan pemasok dan anggota-anggota lain dari rantai nilai seperti distributor.

\section{Asumsi Dasar Target Costing}

Menurut Bustami, (2012) target costing sangat mungkin sesuai bagi perusahaan yang Price Taker dalam suatu pasar yang heterogen, dimana kompetisi menentukan harga jual produk barang/jasa, yang ditandai dengan kharakteristik antara lain:

1. Umumnya tidak layak atau tidak ada kehendak untuk menawarkan produk dengan harga yang tak terjangkau oleh para kompetitor.

2. Keunggulan spesifik suatu perusahaan akan menentukan arah dalam melakukan deferensiasi produk baru dari yang telah ada di pasaran, misalnya (1) Cost Advantage produk yang sama/serupa namun dengan harga yang lebih murah dan (2) Penambahan fungsi, misalnya dengan tambahan fitur baru dengan harga yang kompetitif.

\section{Penerapan Target Costing Untuk Penentuan Harga}

Harga target yang dihitung dengan menggunakan informasi dari pelanggan dan pesaing menjadi dasar untuk menghitung biaya target. Biaya target per unit adalah harga target dikurangi penghasilan operasi target per unit. Penghasilan operasi target per unit adalah penghasilan operasi yang merupakan sasaran yang ingin diperoleh perusahaan per unit produk atau jasa yang dijual. Biaya target per unit adalah perkiraan biaya jangka panjang per unit atas sebuah produk atau jasa yang membuat perusahaan mampu mencapai penghasilan operasi target per unit saat menjual pada harga target, sebuah penentuan harga berbasis pasar adalah penentuan harga target.

Horngren et,al (2008) mengemukakan bahwa Harga target adalah perkiraan harga untuk sebuah produk atau jasa yang bersedia dibayar calon pelanggan. Perkiraan ini didasarkan pada pemahaman tentang nilai yang dipersepsi pelanggan atas sebuah produk dan berapa pesaing akan memberi harga produk yang bersaing itu.

Berikut ini adalah kendala yang kerap dikeluhkan oleh perusahaan yang mencoba menerapkan target costing.

1. Konflik antar kelompok dan atau antar anggota kelompok

2. Karyawan yang mengalami burnout karena tuntutan target penyelesaian pekerjaan

3. Target waktu penyelesaian yang terpaksa ditambah

4. Sulitnya melakukan pengaturan atas berbagai faktor penentu keberhasilan target costing.

\section{METODE}

Jenis penelitian yang digunakan dalam penelitian ini adalah jenis penelitian deksriptif dengan pendekatan kuantatif. Teknik pengumpulan data yang digunakan dalam penelitian ini adalah observasi lapangan dan interview. Jenis data yang digunakan dalam penelitian ini adalah data primer dan data sekunder. Berdasarkan masalah pokok dan tujuan penelitian yang ingin dicapai, maka metode analisis yang digunakan yaitu analisa deskriptif. Metode analisis deskriptif adalah metode yang 
digunakan dengan cara menganalisis dan menguraikan untuk menggambarkan keadaan objek yang diteliti yang menjadi pusat perhatian dalam penelitian. Metode analisis deskriptif secara hakekatnya adalah data yang telah terkumpul itu kemudian diseleksi, dikelompokkan, dilakukan pengkajian, interpretasi dan disimpulkan. Data dalam penelitian ini berupa sejarah singkat perusahaan, struktur organisasi dan informasi lainnya yang relevan dengan penelitian ini.

HASIL DAN PEMBAHASAN

Analisis Biaya Produksi dan Biaya Nonproduksi

Berikut ini merupakan Total Harga Produksi Lemari 2 dan 3 pintu

Tabel 1

\begin{tabular}{|l|rr|}
\hline \multicolumn{1}{|c|}{ Keterangan } & \multicolumn{2}{|c|}{$\begin{array}{c}\text { Biaya Produksi } \\
\text { Lemari 2 Pintu }\end{array}$} \\
\hline Bahan baku Langsung & Rp. & 660.000 \\
\hline Tenaga Kerja Langsung & Rp. & 240.000 \\
\hline Biaya Overhead Pabrik & Rp. & 54.954 \\
\hline Biaya Pengiriman & Rp. & 16.666 \\
\hline Total & Rp. & 971.620 \\
\hline
\end{tabular}

Sumber: Hasil Olah Data (2019)

Tabel 2

\begin{tabular}{|c|c|}
\hline Keterangan & $\begin{array}{l}\text { Biaya Produksi } \\
\text { Lemari } 3 \text { Pintu }\end{array}$ \\
\hline Bahan baku Langsung & Rp. 825.000 \\
\hline Tenaga Kerja Langsung & 300.000 \\
\hline Biaya Overhead Pabrik & 67.453 \\
\hline Biaya Pengiriman & 16.666 \\
\hline Total & Rp. 1.209 .119 \\
\hline
\end{tabular}

Sumber: Hasil Olah Data (2019)

Dapat dilihat pada tabel 1 sampai dengan table 2 telah di lampirkan besarnya biaya bahan baku, Biaya tenaga kerja, dan Biaya overhead pabrik. Dimana masing-masing biaya tersebut di bagi dengan total produksi masing-masing dengan tujuan untuk mendapatkan besarnya biaya untuk satu buah lemari. Oleh karenanya di dapatkan biaya bahan baku untuk pembuatan lemari 2 pintu sebesar Rp. 660.000 sedangkan biaya bahan baku untuk pembuatan lemari 3 pintu sebesar Rp. 825.000. kemudian untuk biaya tenaga kerja sebesar Rp. 240.000 untuk pembuatan lemari 2 pintu dan Rp. 300.000 untuk pembuatan lemari 3 pintu sedangkan untuk biaya overhead pabrik yaitu Rp. 54.954 untuk lemari 2 pintu dan Rp. 67.453

Tabel 3

\begin{tabular}{|l|l|}
\hline \multicolumn{1}{|c|}{ Jenis Lemari } & Harga Jual \\
\hline Lemari 2 Pintu & Rp. 1.250 .000 \\
\hline Lemari 3 Pintu & Rp. 1.500 .000 \\
\hline
\end{tabular}

Sumber: Hasil Olah Data (2019)

Tabel 4

Sumber: Hasil Olah Data (2019)

Untuk biaya pemasaran Usaha Winda yang dimana terdiri atas biaya pengiriman sebesar Rp. 100.000 untuk satu kali pengantaran. Pada tabel 1 di sajikan hasil perhitungan biaya per mebel dimana total biaya/harga pokok untuk lemari 2 pintu sebesar Rp. 971.620 dan Rp. 1.209.119 untuk lemari 3 pintu. Dari hasil perhitungan biaya per mebel disajikan margin laba menurut perusahaan yaitu sebesar 28,65 \% untuk lemari 2 pintu dan $24,05 \%$ untuk lemari 3 pintu yang di mana margin laba tersebut belum memenuhi presentase laba yang diinginkan

\begin{tabular}{|c|c|c|c|c|}
\hline \multirow{2}{*}{$\begin{array}{c}\text { Jenis } \\
\text { Mebe } \\
1\end{array}$} & $\begin{array}{c}\text { Besarnya } \\
\text { Biaya } \\
\text { Menurut }\end{array}$ & $\begin{array}{c}\text { Besarnya } \\
\text { Berusaha } \\
\text { an } \\
\text { (Rp) }\end{array}$ & $\begin{array}{c}\text { Menurut } \\
\text { Target } \\
\text { Costing } \\
\text { (Rp) }\end{array}$ & \multicolumn{2}{|c|}{$\begin{array}{c}\text { Penghematan } \\
\text { Bpiaya }\end{array}$} & $\%$ \\
\hline $\begin{array}{c}\text { Lemari } \\
\text { 2 Pintu }\end{array}$ & 971.620 & 875.000 & 96.620 & 9,94 \\
\hline $\begin{array}{c}\text { Lemari } \\
\text { 3 Pintu }\end{array}$ & 1.209 .119 & 1.050 .000 & 159.119 & 13,15 \\
\hline
\end{tabular}

usaha winda sebesar $30 \%$.

Dari hasil perbandingan antara biaya produksi mebel yang di keluarkan perusahaan dengan biaya menurut metode penggunaan Target costing, Sebelumnya perlu diketahui bahwa target Keuntungan Perusahaan sebesar 30\% dari harga jual, Sedangkan menurut Perusahaan biaya yang dikeluarkan dalam memproduksi lemari 2 pintu sebesar Rp. 971.620 atau $28,65 \%$ sedangkan untuk lemari 3 pintu sebesar Rp.1.209.119 atau 24,05 \% yang di mana tidak memenuhi target perusahaan. Biaya atau harga pokok untuk lemari 2 pintu yang dikeluarkan menurut 
Target costing sebesar Rp. 875.000 atau $42,85 \%$ sedangkan biaya atau harga pokok untuk lemari 3 pintu yang dikeluarkan menurut Target Costing sebesar Rp. 1.050.000 atau $42.85 \%$ yang di mana telah memenuhi target perusahaan.

Dapat dilihat dari total Biaya Produksi Perusahaan bahwa besarnya biaya untuk pembuatan lemari 2 pintu sebesar Rp. 971.620 dan Rp. 1.209.119 untuk pembuatan lemari 3 pintu (angka tersebut diperoleh dengan menjumlahkan seluruh biaya yang termasuk dalam kegiatan produksi) sedangkan menurut target costing untuk pembuatan lemari 2 pintu sebesar Rp. 875.000 dan Rp. 1.050.000 untuk pembuatan lemari 3 pintu. Serta diperoleh penghematan masing- masing sebesar Rp. 96.620 untuk lemari 2 pintu dan untuk lemari 3 pintu sebesar $\mathrm{Rp}$. 159.119. Dengan demikian maka dapat dikatakan bahwa penerapan target costing dapat meningkatkan efisiensi biaya produksi mebel. Oleh karena itu Metode Target costing dapat di jadikan alat bagi UD. Winda dalam mengendalikan biaya produksi sehingga dapat mencapai target laba yang dinginkannya.

Hasil penelitian di atas menunjukkan bahwa target costing merupakan alternatif yang baik dalam upaya menurunkan atau menekan biaya sesuai dengan penelitian sebelumnya yang dilakukan oleh Longdong, (2016) dimana penelitian tersebut mengemukakan keberhasilan metode target costing dalam upaya penurunan biaya perusahaan dengan menggunakan analisis value engineering atau rekayasa nilai produk pada tahap desain yang sangat menentukan karena sebagian besar biaya produk ditentukan dan diantisipasi pada tahap desain. Dalam penelitian tersebut membahas usaha-usaha penurunan biaya pada tahap produksi di perusahaaan garmen yang dilakukan dengan menekan pemborosan-pemborosan pada saat pengadaan barang, penyimpanan bahan, proses pemakaian bahan dan penjahitan, dan pada proses pengemasan dan penyerahan produk ke pasar. Kalkulasi biaya-biaya pada sub-bab sebelumnya merupakan gambaran atau deskripsi dari penerapan metode target costing sebagai alternatif yang penulis rekomendasikan kepada perusahaan agar dapat menekan biaya produksinya guna mendapatkan keuntungan sesuai dengan target laba yang diinginkan perusahaan, jika perusahaan ingin mendapatkan keuntungan maksimum perusahaan perlu mengaplikasikan metode tersebut, namun semua keputusan adalah hak dari kepala perusahaan untuk menerapkan metode apa yang harus digunakannya agar perusahaan dapat mendapatkan keuntungan yang maksimal.

Biaya target per unit adalah harga target dikurangi penghasilan operasi target per unit. Penghasilan operasi target per unit adalah penghasilan operasi yang merupakan sasaran yang ingin diperoleh perusahaan per unit produk atau jasa yang dijual. Biaya target per unit adalah perkiraan biaya jangka panjang per unit atas sebuah produk atau jasa yang membuat perusahaan mampu mencapai penghasilan operasi target per unit saat menjual pada harga target, sebuah penentuan harga berbasis pasar adalah penentuan harga target.

Pada rencana dan kebijakan perusahaan sebelumnya yang sifatnya masih sederhana dan tidak terdapat perencanaan manajemen yang baik untuk mengendalikan biaya yang seharusnya dikeluarkan perusahaan, perusahaan perusahaan hanya terfokus pada penyediaan bahan baku utama berupa kayu yang harus selalu tersedia ketika perusahaan akan memproduksi produk lemari, tanpa memberi rencana yang tepat bahwa dalam waktu kurun waktu tertentu perusahaan harus memiliki berapa banyak persediaan bahan baku. Kejadian tersebut menyebabkan tidak terkendalinya biayabiaya yang seharusnya terjadi, sehingga perusahaan sulit untuk merencanakan berapa banyak atau berapa jumlah keuntungan yang seharusnya menjadi target perusahaan. Begitu pula dalam menentukan harga jual atau dalam 
perhitungan biaya produksi, sebelumnya perusahaan menerapkan kebijakan yang tergolong metode traditional cost.

Perusahaan hanya melihat biaya-biaya yang langsung terjadi ketika melakukan aktifitas produksi, tanpa melihat faktor biaya lain seperti biaya overhead pabrik. Harga produk yang terjadi pun hanya didapat dari pengakumulasian biaya-biaya yang langsung terjadi dan harga ditentukan sesuai berkembangnya harga di pasaran. Berdasarkan hasil penelitian dalam menerapkan metode target costing pihak Usaha Winda dapat merencanakan bagaimana mendesain ulang biaya sedemikian rupa mulai dari mengganti faktorfaktor yang mempengaruhi tingginya biaya yang terjadi pada desain biaya produk sebelumnya.

Harga target yang dihitung dengan menggunakan informasi dari pelanggan dan pesaing menjadi dasar untuk menghitung biaya target. Sehingga dapat dijadikan tolak ukur dimana perusahaan dapat dengan mudah melihat sejauh mana perusahaan menentukan standarisasi harga dan kualitas produk. Melalui pengendalian biaya, penerapan target costing dilakukan dengan mengidentifikasi berapa harga yang diinginkan pasar dan kemudian mendesain produk yang bersedia dibayar oleh pasar tersebut. Dalam hal ini perusahaan menetapkan harga jual yang terbaru dan masih berlaku pada pasar dari produk tersebut, maka dari itu dengan metode target costing perusahaan akan dapat lebih mudah untuk mencapai laba yang ditargetkan yaitu sebesar 30\% dari setiap satu unit produk yang dipasarkan.

\section{SIMPULAN}

Berdasarkan hasil pembahasan diatas, maka dapat ditarik beberapa kesimpulan sebagai berikut:

1. Berdasarkan hasil perhitungan mengenai penerapan target costing, menunjukkan bahwa penerapan target costing pada UD. Winda lebih efisien jika dibandingkan dengan yang dilakukan oleh perusahaan selama ini, dan juga merupakan alternatif yang baik bagi erusahaan untuk menekan biaya produksinya, dimana dengan penerapan target costing, perusahaan dapat memperoleh penghematan biaya sebesar 9\% hingga 13\% dari biaya yang dikeluarkan sebelum menggunakan metode target costing.

2. Biaya produksi pembuatan lemari 2 pintu pada UD. Winda sebesar Rp. 971.620, sedangkan besarnya biaya produksi dengan menggunakan metode Target Costing adalah Rp. 875.000. Biaya produksi pembuatan lemari 3 pintu pada UD. Winda sebesar Rp. 1.209.119, sedangkan besarnya biaya produksi dengan menggunakan metode Target Costing adalah Rp. 1.050.000.

3. Penerapan metode target costing pada UD Winda dapat berperan sebagai alat pengendalian biaya produksi. Hal ini ditunjukkan dengan penurunan harga pokok produksi pembuatan Lemari dimana untuk pembuatan lemari 2 pintu diperoleh penurunan sebesar Rp 92.620 dan untuk pembuatan lemari 3 pintu sebesar Rp 159.119. Penurunan biaya itu tidak mengubah kualitas hasil produksi dan memungkinkan peningkatan laba yang optimal dengan tetap mengacu pada harga jual kompetitif di pasar.

\section{Saran}

Adapun saran dari hasil penelitian ini yaitu:

1. Untuk mencapai Target Costing yang diinginkan, maka disarankan untuk mengontrol penggunaan bahan baku dan bahan baku pendukung dalam proses produksi pembuatan lemari. Ini dilakukan untuk menghindari bahan baku dan pendukung yang terbuang percuma.

2. Bagi peneliti berikutnya penulis menyarankan untuk lebih memvariasikan variabel-variabel yang dapat dihubungkan dengan penerapan metode target costing dan juga menggunakan kedua metode pengendalian biaya yang termasuk dalam teknik analisis target costing 
yaitu kaizen costing dan value engineering, karena pada penelitian ini masih menggunakan variable-variabel yang tidak jauh berbeda dari penelitipeneliti sebelumnya serta hanya menggunakan metode pengendalian biaya value engineering saja. Serta mempersiapkan penelitian tersebut dengan seksama mulai dari lamanya waktu penelitian hingga periode data yang diperoleh dari perusahaan agar lebih akurat dalam mendapatkan hasil penelitian dari target costing secara lebih mendalam.

\section{DAFTAR PUSTAKA}

Bustami, B. dan N. (2012). Manajemen Biaya (4th ed.). Salemba EMpat.

Caroline, T. C. dan Wokas, H. R. N. (2016). Analisis Penerapan Target Costing dan Activity-Based Costing Sebagai Alat Bantu Manajemen Dalam Pengendalian Biaya Produksi Pada UD. Bogor Bakery. Jurnal Emba, 4(1).

Hansen dan Mowen. (2001). Akuntansi Manajemen Biaya Jilid 2. Salemba EMpat.

Horngren et. (2008). Akuntansi Biaya Jilid 1. Erlangga.

Longdong, F. M. (2016). Penerapan Target Costing Dalam Perencanaan Biaya Produksi Pada CV. Sinar Mandiri. Universitas Sam Ratulangi. Jurnal Emba, 4(1).

Malue, J. (2013). Analisis Penerapan Target Costing Sebagai Sistem Pengendalian Biaya Produksi Pada PT. Celebes Mina Pratama, Manado. Jurnal Emba, 1(3).

Mulyadi. (2012). Akuntansi Biaya (5th ed.). UPP STIM YKPN.

Rahmaji. (2013). Penerapan ActivityBased Costing System Untuk Menentukan Harga Pokok Produksi Pada PT. Celebes Mina Pratama. Jurnal Emba, 1(3).

Rahmat, M. A. (2013). Penerapan Target
Costing dalam Penentuan Tarif Kamar untuk Mengoptimalkan Perencanaan Laba ( Studi Kasus pada UB Hotel Malang ). Jurnal Akuntansi Universitas Brawijaya.

Supriyono. (2010). Akuntansi Biaya: Perencanaan dan Pengendalian Biaya Serta Pembuatan Keputusan. Edisi Kedua. BPEF. 